\title{
Nitrogen resorption and fractionation during leaf senescence in typical tree species in Japan
}

\author{
Ayako Enta ${ }^{1} \cdot$ Mika Hayashi $^{1} \cdot$ \\ Maximo Larry Lopez Caceres ${ }^{1} \cdot$ Lei Fujiyoshi $^{2}$. \\ Toshiro Yamanaka $^{3} \cdot$ Akira Oikawa $^{1} \cdot$ Felix Seidel $^{1}$
}

Received: 2 November 2018 / Accepted: 4 March 2019 / Published online: 22 October 2019

(C) The Author(s) 2019

\begin{abstract}
In northeastern Japan, an area of high precipitation and mountains, beech (Fagus creanata Blume), larch (Larix kaempferi Lamb.), cedar (Cryptomeria japonica D. Don) and black locust (Robinia pseudoacacia L.) were evaluated for $\mathrm{N}$ resorption and $\mathrm{N}$ isotope fractionation in preand post-abscission leaves in comparison to green leaves. The highest leaf $\mathrm{N}$ concentration in summer corresponded to the $\mathrm{N}$-fixing black locust, followed in decreasing order by the deciduous beech and larch and evergreen cedar. On the other hand, the lowest $\mathrm{N}$ resorption efficiency corresponded to black locust and the highest to beech, in increasing order by larch and cedar. All tree species returned significant amounts of $\mathrm{N}$ before leaf abscission; however, $\mathrm{N}$ isotope fractionation during leaf $\mathrm{N}$ resorption was only found for beech, with a depleted $\mathrm{N}$ isotope value from green to pre-abscission leaf. The most N, however, was resorbed from pre-abscission to post-abscission. This result may indicate that $\delta^{15} \mathrm{~N}$ fractionation took place during $\mathrm{N}$ transformation processes, such as protein hydrolysis, when the concentration of free amino acids increased sharply. The difference in the type of amino acid produced by each species could have influenced the $\mathrm{N}$
\end{abstract}

The online version is available at http://www.springerlink.com

Corresponding editor: Yanbo Hu.

Maximo Larry Lopez Caceres

larry@tds1.tr.yamagata-u.ac.jp

1 Faculty of Agriculture, Yamagata University, Wakabamachi 1-23, Tsuruoka 997-8555, Japan

2 Research Institute for Humanity and Nature, Motoyama 457-4, Kamigamo, Kita-ku, Kyoto 603-8047, Japan

3 Department of Ocean and Environmental Sciences, Tokyo University of Marine Science and Technology, 4-5-7 Konan Minato-ku, Tokyo 108-8477, Japan isotope ratio in beech but not in the other tree species. The results of this study showed that it is possible to infer the type and timing of processes relevant to $\mathrm{N}$ resorption by analyzing leaf $\delta^{15} \mathrm{~N}$ variation during senescence.

Keywords Amino acids $\cdot$ Cool temperate forest $\cdot$ Fresh litter $\cdot \mathrm{N}$ resorption $\cdot \delta^{15} \mathrm{~N}$

\section{Introduction}

Nitrogen is one of the main elements necessary for forest ecosystem growth. However, its acquisition is limited by $\mathrm{N}$ mineralization and $\mathrm{N}$ loss through processes such as leaching and volatilization (Vergutz et al. 2012). Therefore, a key function for plants is the retention of nutrients via resorption from senescing leaves at the end of the growing season. Plants generally reabsorb half of their total leaf $\mathrm{N}$, yet there is large interspecific variation in the extent of $\mathrm{N}$ resorption (Aerts 1996; Yuan and Chen 2009). The stored $\mathrm{N}$ is reallocated mainly to the stem and roots for new growing tissues the next spring (Millard 1994; van Heerwaarden et al. 2003; Singh 2014, 2015).

$\mathrm{N}$ resorption reflects plant dependence on soil $\mathrm{N}$ supply, with leguminous species having a lower $\mathrm{N}$ resorption efficiency (NRE) (Singh 2014, 2015). The resorbed N is stored in plant tissues after leaf senescence (van Heerwaarden et al. 2003; Vergutz et al. 2012; Chavez-Vergara et al. 2015); thus, deciduous trees having a significantly higher NRE than evergreen trees (Aerts 1996; Yuan and Chen 2009). Previous studies have also shown that $\mathrm{N}$ resorption proficiency (NRP) ( $\mathrm{N}$ content per dry leaf mass in senescing leaves) is a useful parameter for quantifying the amount of actual $\mathrm{N}$ that returns to storage tissues (Wright and Westoby 2003; Lima et al. 2006; Özbucak et al. 2008; Chavez-Vergara et al. 2015). In 
mixed forests, tree species with lower NRE contribute more $\mathrm{N}$ in the leaf litter, which thus increases $\mathrm{N}$ availability in the soil (Lopez et al. 2014; Chavez-Vergara et al. 2015) and provides $\mathrm{N}$ to neighboring plants. Even though many studies have dealt with the process of resorption, very few studies have used isotope analysis to examine $\mathrm{N}$ isotope discrimination during this process (Kolb and Evans 2002; Templer et al. 2007), especially in the context of the duration of resorption. The use of stable isotopes is relevant because of the effect of free amino acids release during protein hydrolysis (Chapin and Kedrowski 1983; Vitousek et al. 1989) on foliar $\delta^{15} \mathrm{~N}$ as the concentration of free amino acids in leaves increase (Killingbeck 2004; Mae 2004) during the first stage of $\mathrm{N}$ withdrawal.

Foliar $\delta^{15} \mathrm{~N}$ varies by over 32\%o among plants found in natural ecosystems (Yoneyama et al. 1993; Aranibar et al. 2004; Codron et al. 2005; Hobbie et al. 2005) and systematically along gradients of climate and nutrient cycling (Amundson et al. 2003; Pardo et al. 2006; Craine et al. 2009) and among species (Michelsen et al. 1996; Hobbie et al. 2005; Templer et al. 2007; Kahmen et al. 2008). Differences during the growing season have been reported (Handley et al. 1999), but other studies found no difference during that period (Pardo et al. 2006, 2013). Discrimination of ${ }^{15} \mathrm{~N}$ could potentially occur during either the biochemical processes involved in $\mathrm{N}$ resorption from senescing leaves and thus cloud interpretations of community-wide patterns of foliar $\delta^{15} \mathrm{~N}$. Amino acids are the primary transport form of $\mathrm{N}$, but as $\mathrm{N}$ mostly occurs in proteins and chlorophylls, biochemical processes are needed to convert the $\mathrm{N}$ to transportable forms (Fotelli et al. 2002; Ueda et al. 2011). Protein hydrolysis, like many biochemical reactions, may involve discrimination against ${ }^{15} \mathrm{~N}$, which could lead to variation in the isotopic composition of different plant tissues (Shearer and Kohl 1989; Babst and Coleman 2018), which would be also expected during chlorophyll degradation.

The present study addresses whether $\mathrm{N}$ discrimination occurs during leaf $\mathrm{N}$ resorption by examining patterns of $\delta^{15} \mathrm{~N}$ prior and during leaf senescence in four types of functional groups of trees that are typical for Japan: deciduous (Fagus crenata Blume; Fagaceae), deciduous-coniferous (Larix kaempferi Lamb.; Laraceae), evergreen (Cryptomeria japonica D. Don) and invasive legume (Robinia pseudoacacia L.; Leguminosae).

Many of the studies on $\mathrm{N}$ resorption have focused on comparing the leaf $\mathrm{N}$ concentration between mature and abscised leaves (Negi and Singh 1993; Özbucak et al. 2008; Chavez-Vergara et al. 2015), but very few have focused on the duration of this resorption (Chapin and Kedrowski 1983; Wang et al. 2013). This study aimed to clarify the response of the $\mathrm{N}$ cycle in representative species in a heavy rainfall area, such as northeastern Japan, by focusing on the amount of $\mathrm{N}$ being returned to trees or input in the soil as litter and by tracing stable isotopes in the $\mathrm{N}$ fraction that is recycled within the forest ecosystem. We, thus compared the NRE of the four tree species and evaluated the effects of $\mathrm{N}$ transformation processes on $\mathrm{N}$ isotope discrimination during resorption.

\section{Materials and methods}

\section{Study area}

This study was conducted at the Yamagata University Research Forest, Japan (38 $33^{\circ} \mathrm{N}, 139^{\circ} 51^{\prime}$ E) (Fig. 1) in the northernmost area of the Asahi Mountains, a cool temperate deciduous broad-leaved forest zone. The annual mean air temperature is $13.4^{\circ} \mathrm{C}$, mean annual precipitation is $2500 \mathrm{~mm}$, and mean snow depth is approximately $3 \mathrm{~m}$.

Four types of functional groups typical in this region were investigated: black locust (R. pseudoacacia; Leguminosae), deciduous beech (F. crenata; Fagaceae), larch (L. kaempferi; Pinaceae) and cedar (C. japonica; Cupressaceae) were sampled in forest stands that were close to each other (Fig. 1); each species was dominant in its stand. The invasive black locust stand invaded a former cedar forest site that was cut and cleared by slash and burn in 2011. The beech stand is natural for this area and most common, followed by the cedar plantations. The age of the sampled larch and cedar plantations was around 60 years, similar to the beech stand, while the black locust stand was the youngest at 7 years.

\section{Meteorological conditions}

The meteorological station in the Yamagata University Research Forest is located near the sampled sites (Fig. 1). During each month from June to November in 2016, at least $100 \mathrm{~mm}$ precipitation fell, with $47 \%$ of the precipitation in July and August, when air temperatures $\left(T_{\mathrm{a}}\right)$ was the highest. Precipitation then decreased until January 2017 (Fig. 2).

\section{Sampling}

The leaf and needle samples for the selected tree species were collected three times between August and November 2016. The first sampling took place during the first week of August when maximum growth was reached, as indicated by installed dendrometers, and the maximum mass $\mathrm{N}$ pool sizes are expected (Chapin and Kedrowski 1983). This period is defined as green leaf, while the second sampling period, defined as pre-abscission, took place in mid-October when more than $10 \%$ of the deciduous trees leaves were starting to change colors. The post-abscission samples were collected by mid-November, assuming that leaching between leaf fall and leaf 


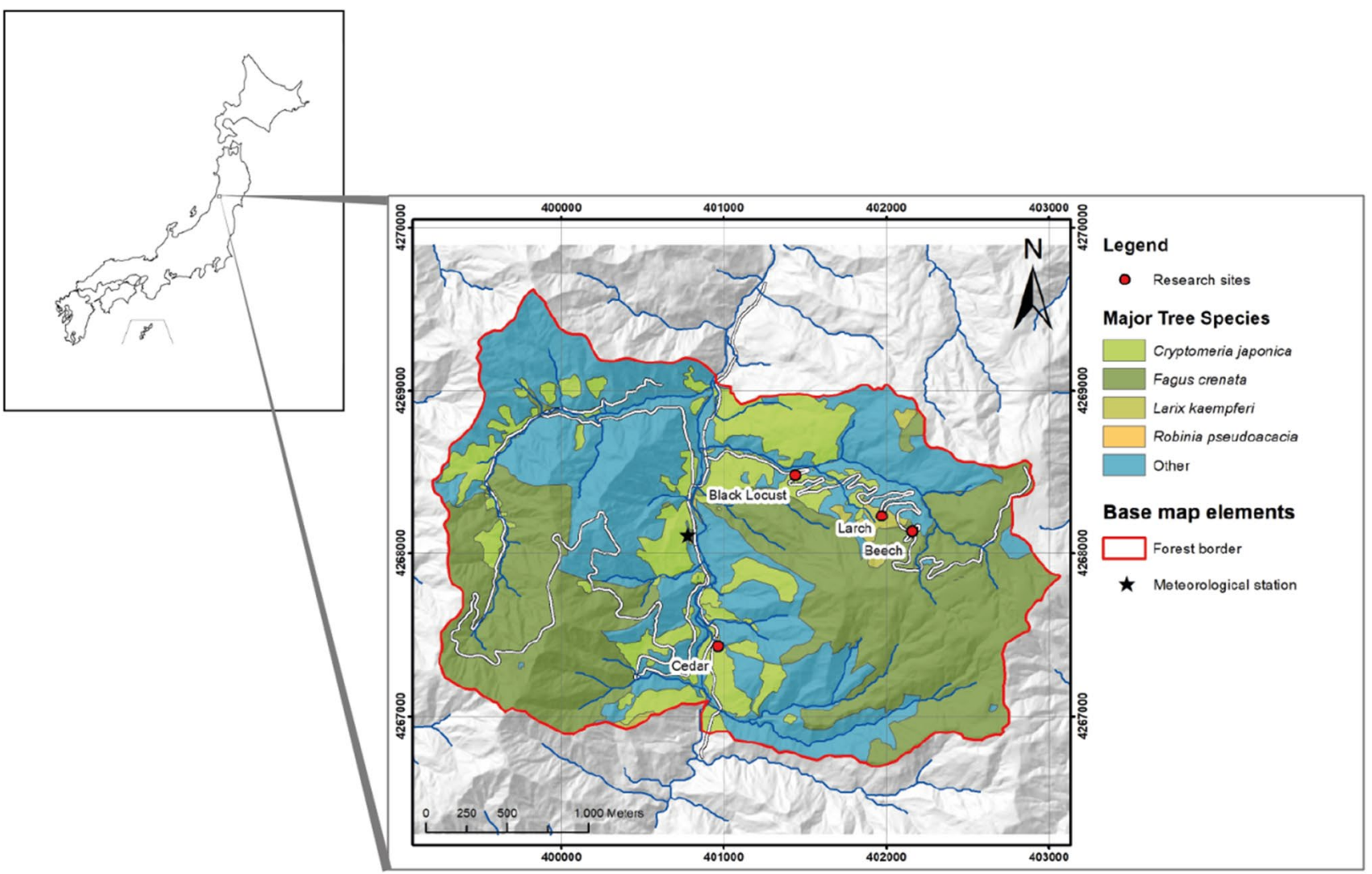

Fig. 1 Study sites with beech, larch, cedar and black locust stands in the Yamagata University Research Forest, Japan

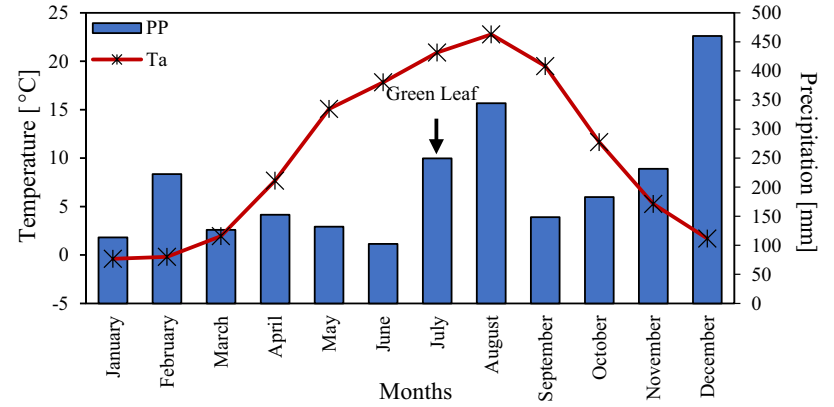

Fig. 2 Meteorological conditions at the Yamagata University Research Forest in 2016

collection was negligible (Vergutz et al. 2012). The leaf samples in August and October were collected randomly from eight cedar and eight black locust trees and from six larch and six beech trees. All leaf samples were selected to avoid leaves that were damaged by insects (Özbucak et al. 2008) and taken from branches that were at a reachable height. To collect the post-abscission leaf samples, three $80 \times 80 \mathrm{~cm}$ litter traps were set up in each of the four stands from the second week of September until the second week of November. Leaf samples of cedar were not divided by leaf age groups because $\mathrm{N}$ concentrations were previously found not to differ among ages (Kobayashi and Tashiro 2003).

\section{Analysis}

$N$ concentration $(\% N)$ and $\delta^{15} N(\% \circ)$

All leaf samples were oven dried at $70^{\circ} \mathrm{C}$ for $48 \mathrm{~h}$, ground, then $\mathrm{N}$ concentration and $\delta^{15} \mathrm{~N}$ were measured with a CFIRMS (continuous-flow type mass spectrometer: Iso Prime mass spectrometer, GV Instruments, Withenshave, UK). The evolved gas was first passed through a column of packed solid $\mathrm{CaO}-\mathrm{NaOH}$ (soda lime) to eliminate excess $\mathrm{CO}_{2}$ and then introduced into a gas chromatograph to separate $\mathrm{N}_{2},{ }^{15} \mathrm{~N} /{ }^{14} \mathrm{~N}$ ratios were determined with the mass spectrometer. Analytical errors associated with the overall procedure for $\delta^{15} \mathrm{~N}$ measurement are less than $0.2 \%$. The results of $\delta^{15} \mathrm{~N}$ were expressed as \%o deviation, relative to atmospheric $\mathrm{N}_{2}\left(\delta^{15} \mathrm{~N}=0 \%\right.$ ):

$$
\delta^{15} \mathrm{~N}=\left(\frac{\left({ }^{15} \mathrm{~N} /{ }^{14} \mathrm{~N}\right)_{\text {sample }}}{\left({ }^{15} \mathrm{~N} /{ }^{14} \mathrm{~N}\right)_{\text {standard }}}-1\right) .
$$


Nitrogen resorption efficiency (NRE) and resorption proficiency (NRP)

NRE is calculated as the difference between the $\mathrm{N}$ concentration in the green leaves and the $\mathrm{N}$ concentration in leaves after abscission divided by the $\mathrm{N}$ concentration in green leaves, and is expressed as a percentage:

$\mathrm{NRE}=\left(1-\frac{\text { mass of } \mathrm{N} \text { in senesced leaves }}{\text { mass of } \mathrm{N} \text { in greeen leaves }}\right) \times 100$.

In addition, $\mathrm{N}$ resorption efficiency was corrected according to method of Vergutz et al. (2012) (NRE*) by multiplying NRE by the mass loss correction factor of 0.754 for conifers and 0.784 for deciduous angiosperms (Vergutz et al. 2012), because loss in leaf mass during senescence can lead to an underestimation of $10 \%$ (van Heerwaarden et al. 2003).

$\mathrm{NRP}$, that is, $\mathrm{N}$ concentration per leaf mass in senescing leaves (in \% dry mass), is used as a more stable indicator of plant ability to recycle nutrients than NRE (Killingbeck 2004; Yasumura et al. 2005; Yuan et al. 2005). Leaves that can reduce $\mathrm{N}$ concentration to a lower level are more proficient in resorbing $\mathrm{N}$.

\section{Amino acid content}

All samples were oven dried at $70{ }^{\circ} \mathrm{C}$ for $48 \mathrm{~h}$, ground, and analyzed for amino acid content by capillary electrophoresis and mass spectrometry (CE-TOFMS, CE type, TOF/MS 6224 , Agilent Technologies). The sample extraction, preparation and CE/MS analysis were done using the methods of Oikawa et al. (2015). Three samples for each period (green leaf, pre-abscission and post-abscission) were analyzed.

\section{Statistical analyses}

The data were subjected to analysis of variance (ANOVA) and a two-way ANOVA (Statcel 2.0, OMS, Tokyo, Japan) to compare the effects of different sample periods and tree species. Changes of all measured parameters in leaves and needles along the three sampling times within one species were compared first ( $\mathrm{n}=8$ for cedar and black locust, $\mathrm{n}=6$ for larch and beech) followed by a comparison of leaf and needle values along sampling times between species. The significant difference was determined with the Tukey-Kramer test $(p<0.05)$.

\section{Results}

\section{Nitrogen concentration, NRE and NRP}

All investigated species exhibited different trends in $\% \mathrm{~N}$ from green leaf to post-abscission, with the $\% \mathrm{~N}$ response of a species affected by a significant species by phenological date interaction $\left(F_{6,32}=6.75 ; p<0.001\right)$. First, $\% \mathrm{~N}$ in beech had a significant decreasing trend across the phenological stages, from green to pre-abscission (19.8\%) and from pre- to post-abscission (48.8\%). Larch and cedar had a similar pattern but with no significant decrease from green leaf $(1.7 \pm 0.3 \% \mathrm{~N}$ and $1.4 \pm 01 \% \mathrm{~N})$ to pre-abscission $(1.4 \pm 0.3 \% \mathrm{~N}$ and $1.3 \pm 0.2 \% \mathrm{~N})$. However, the $\% \mathrm{~N}$ was significantly lower in the post-abscission period $(0.8 \pm 0.0 \% \mathrm{~N}$ and $0.8 \pm 0.2 \% \mathrm{~N})$. Finally, black locust had greater $\% \mathrm{~N}$ than in the other species; although the level remained higher across the phenological stages, it had non-significant decreases from green to pre-abscission and from preto post-abscission leaves (10.3\% and $7.7 \%$, respectively).

All investigated species had a continuous decrease in $\% \mathrm{~N}$ from green leaf to post-abscission. Beech and larch $\mathrm{N}$ concentration had no significant difference in mean $\% \mathrm{~N}$ for the overall period, while the leaf $\mathrm{N}$ concentration in black locust was more than double the concentration in larch and cedar (Fig. 3).

The $\% \mathrm{~N}$ in beech decreased significantly among the sampling periods and was the only tree species with a significant decrease in $\mathrm{N}$ concentration for each period (19.8\% decrease from green to pre-abscission, $48.8 \%$ from pre- to post-abscission). Larch and cedar had a similar pattern but the decrease was not significant from green leaf $(1.7 \pm 0.3 \% \mathrm{~N}$ and $1.4 \pm 01 \% \mathrm{~N})$ to pre-abscission $(1.4 \pm 0.3 \% \mathrm{~N}$ and $1.3 \pm 0.2 \% \mathrm{~N})$, but $\% \mathrm{~N}$ was significantly lower in the post-abscission period $(0.8 \pm 0.0 \% \mathrm{~N}$ and $0.8 \pm 0.2 \% \mathrm{~N})$. For black locust, $\mathrm{N}$ concentration from green to pre-abscission decreased by $10.3 \%$ and from preto post-abscission leaves by $7.7 \%$.

Beech leaves had the highest NRE (68.7\%) among the four species, black locust the lowest (18.0\%). The NRE of larch $(50.9 \%)$ was slightly higher than cedar $(42.6 \%)$ and in-between the values for beech and black locust. Correspondingly, the NRP was the highest (= least proficient) for black locust followed by larch and cedar trees and low values for beech trees (Table 1). The NRE and NRE* showed the same significant differences between beech and locust and the other species, while no difference was found between larch and cedar. In the case of NRP there was no significant difference among beech, larch and cedar but black locust was significantly different to all the other tree species. 
Fig. 3 Mean $( \pm S D) N$ concentration in all selected tree species at three sampling times. Lower case letters indicate a significant difference within a species; upper case letters indicate a significant interaction between species and sampling time $(\alpha<0.05)$

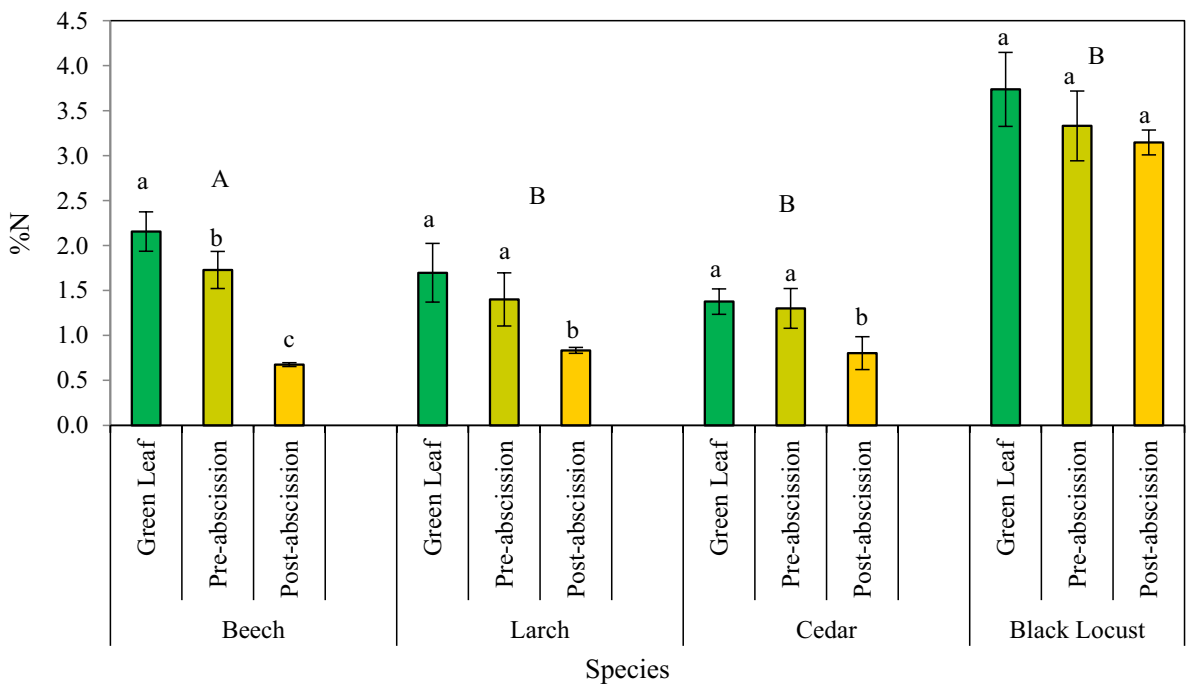

Table 1 Nitrogen resorption efficiency (NRE), corrected nitrogen resorption efficiency $\left(\mathrm{NRE}^{*}\right)$ and nitrogen resorption proficiency (NRP) for the four tree species

\begin{tabular}{llll}
\hline & NRE $(\%)$ & NRE* $\left.^{*} \%\right)$ & $\begin{array}{l}\text { NRP }(\% \\
\text { dry mass })\end{array}$ \\
\hline Beech & $68.7^{\mathrm{a}}$ & $75.4^{\mathrm{a}}$ & $0.7^{\mathrm{a}}$ \\
Larch & $50.9^{\mathrm{b}}$ & $63.4^{\mathrm{b}}$ & $0.8^{\mathrm{a}}$ \\
Cedar & $42.6^{\mathrm{b}}$ & $57.3^{\mathrm{b}}$ & $0.8^{\mathrm{a}}$ \\
Black locust & $18.0^{\mathrm{c}}$ & $35.0^{\mathrm{c}}$ & $3.2^{\mathrm{b}}$ \\
\hline
\end{tabular}

Lower case letters indicate significant differences between species $(\alpha<0.05)$

\section{Leaf amino acids}

The total amino acid content in beech, larch and black locust significantly increased from green leaves $\left(0.8 \pm 0.3 \mathrm{mg} \mathrm{g}^{-1}\right.$, $0.2 \pm 0.1 \mathrm{mg} \mathrm{g}^{-1}$ and $0.2 \pm 0.1 \mathrm{mg} \mathrm{g}^{-1}$ respectively) to preabscission leaves $\left(3.2 \pm 0.4 \mathrm{mg} \mathrm{g}^{-1}, 2.1 \pm 0.3 \mathrm{mg} \mathrm{g}^{-1}\right.$ and $3.2 \pm 0.9 \mathrm{mg} \mathrm{g}^{-1}$, respectively), then decreased significantly in post abscission leaves $\left(1.1 \pm 0.5 \mathrm{mg} \mathrm{g}^{-1}, 0.1 \pm 0.0 \mathrm{mg} \mathrm{g}^{-1}\right.$ and $0.7 \pm 0.3 \mathrm{mg} \mathrm{g}^{-1}$ respectively). The main amino acids that increased, but to a different extent for these three species, were alanine (Ala), asparagine (Asn), glutamine (Gln), isoleucine (Ile), leucine (Leu) and valine (Val). The level of most amino acids in cedar leaves did not differ significantly during the growing season; only arginine (Arg), Asn, glutamic acid (Glu) and tryptophan (Trp) varied significantly (Fig. 4).

\section{Leaf $\delta^{15} \mathrm{~N}$ at different growth periods}

Beech was the only species in which leaf $\delta^{15} \mathrm{~N}$ was significantly higher at the green leaf period $(-1.5 \pm 0.5 \%$ ) than at the pre- $(-2.6 \pm 0.3 \%$ ) and at the post-abscission
$(-2.7 \pm 0.4 \%$ o $)$ periods, but did not differ significantly between the pre- and post-abscission. Although larch leaf $\delta^{15} \mathrm{~N}$ was lower at each consecutive sampling $(0.5 \pm 1.0 \%$ o to $0.0 \pm 1.1 \%$ o to $-0.9 \pm 0.1 \%$ ) , differences among periods were not significant. Cedar and black locust each only changed slightly in leaf $\delta^{15} \mathrm{~N}$ among the periods (cedar was slightly depleted: $-0.4 \%$ from green leaf $[-2.2 \pm 0.5 \%$ o $]$ to post-abscission stage $[-2.6 \pm 0.5 \%$ ]; black locust was slightly enriched: $0.2 \%$ from green leaf $[0.0 \pm 0.3 \%$ o $]$ to pre-abscission $[0.2 \pm 0.5 \%$ ] ) (Fig. 5). The statistical analysis showed that ${ }^{15} \mathrm{~N}$ response was species specific with a significant species by sampling date interaction $\left(F_{6,32}=7.75\right.$; $p<0.0001)$.

Leaf $\delta^{15} \mathrm{~N}$ for all non-leguminous tree species decreased with time, and was slightly enriched in black locust. The average value for the whole period in beech and cedar were depleted and in a similar range, while larch and black locust leaves were significantly enriched.

\section{Discussion}

\section{N concentration, NRE and NRP}

The decrease in $\mathrm{N}$ concentration from green to pre-abscission leaves was greatest in beech trees. In our study, NRE for beech was $68.7 \%$, higher than that for beech trees in Spain (59.4\%) (Santa Regina and Tarazona 2001), but agreed with findings of Vergutz et al. (2012) who reported a decrease in NRE with latitude, mean annual temperature (MAT) and mean annual precipitation (MAP). Beech NRE* in our study was $11.2 \%$ higher than in deciduous angiosperms in a global comparison of different species in different climate zones (Vergutz et al. 2012), which could be due to the high MAP (3000 mm) in our study area. Similarly, Yasumura 
Fig. 4 Mean ( \pm SD) concentration of amino acids in the four tree species at the three sampling times. Asterisks indicate a significant difference in a given amino acid among the three times
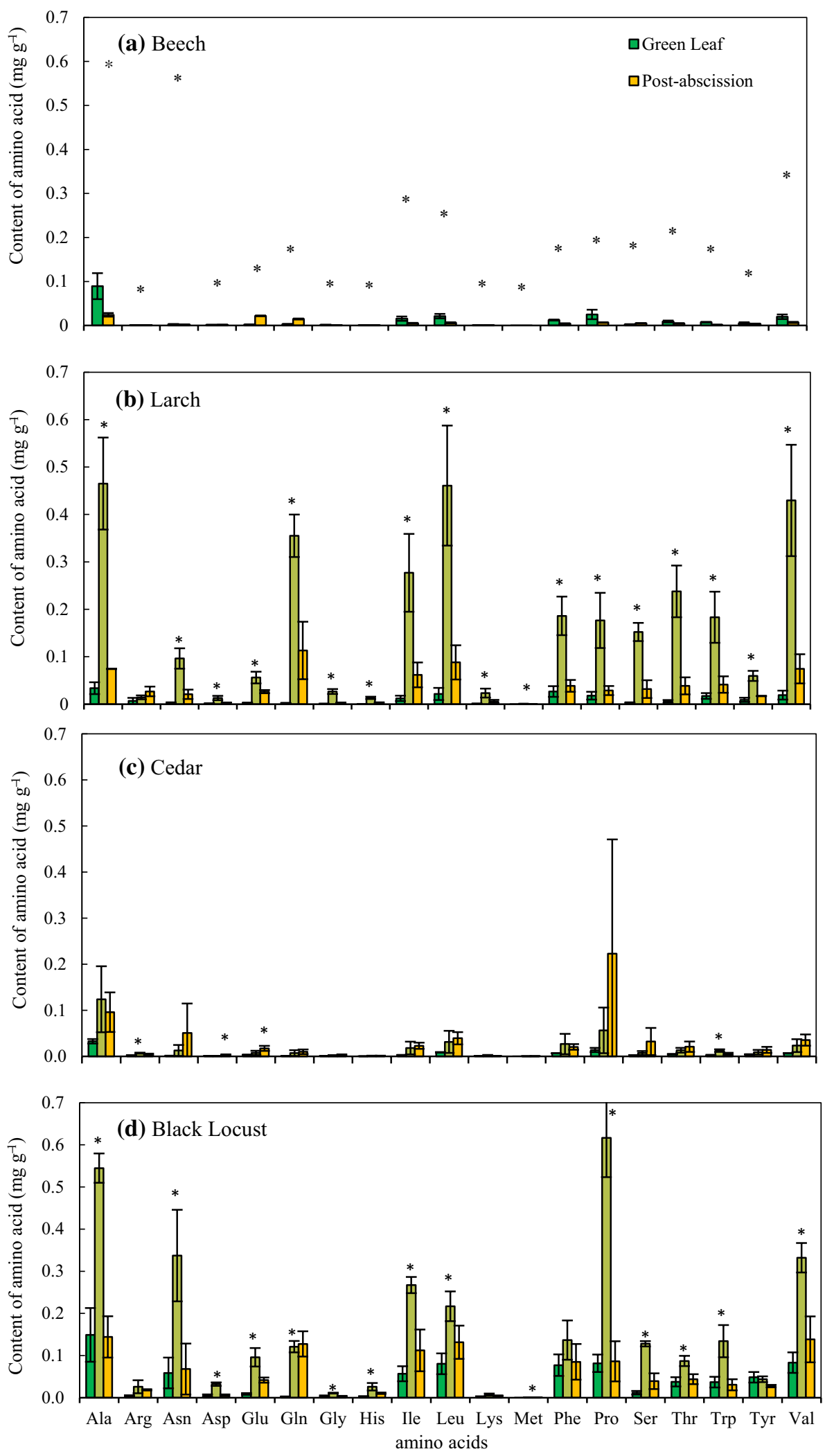
Fig. 5 Mean $\left( \pm\right.$ SD) leaf $\delta^{15} \mathrm{~N}$ in four tree species at three sampling periods. Lower case letters indicate a significant difference within a species; upper case letters indicate a significant interaction between species and sampling period $(\alpha<0.05)$

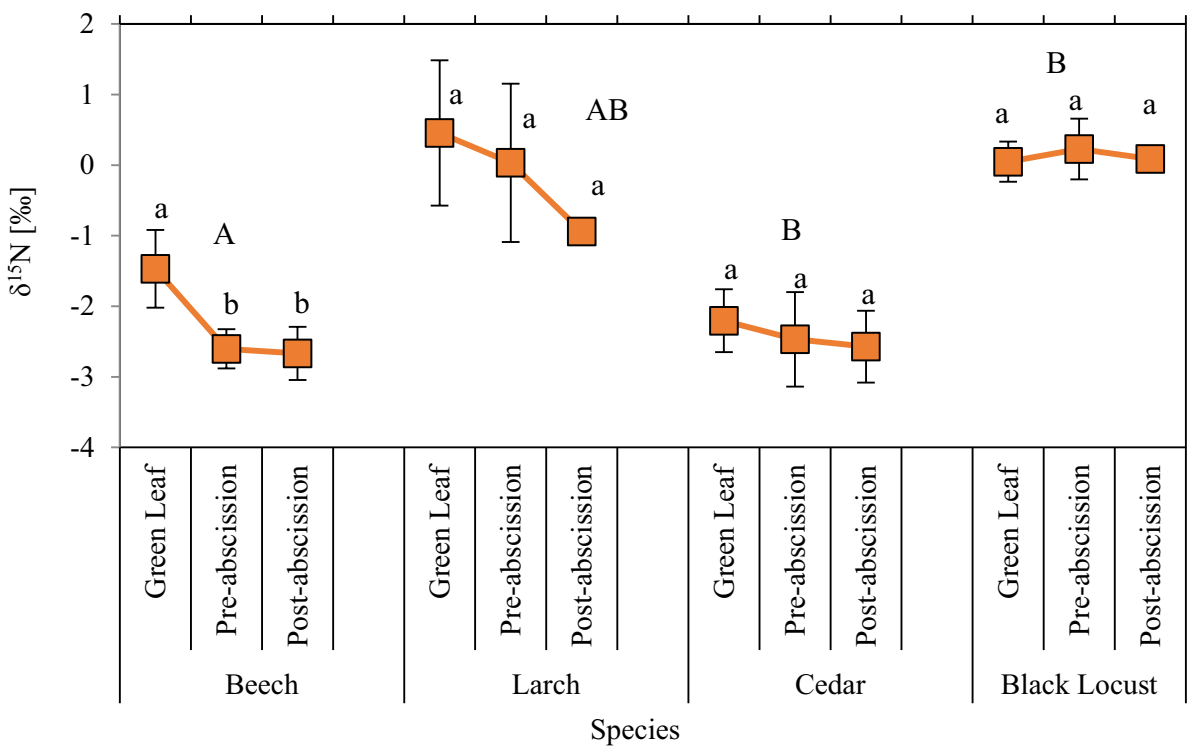

et al. (2005) found NRE values of nearly $70 \%$ for beech $(F$. crenata) in northern Japan. The green leaf $\mathrm{N}$ concentration in beech in our study was similar to that found by Tateno and Takeda (2010) for beech in Japan (20.7 $\mathrm{mg} \mathrm{g}^{-1}$ ).

The green leaf $\mathrm{N}$ concentration for larch was not significantly different from that of beech, but $\mathrm{N}$ resorption took place over a shorter period than for beech, mainly from October to November. NRE* of larch was in the same range for conifers (Vergutz et al. 2012), while for the evergreen coniferous cedar, the leaf $\mathrm{N}$ concentration decrease was similar to that found in larch leaves, but the NRE* was lower. A reason might be that cedar needles were not separated by age and were pooled together; however, Kobayashi and Tashiro (2003) reported values ( $\mathrm{N}$ content: $16.7 \mathrm{mg} \mathrm{g}^{-1}$ for, NRE: $49.1 \%$ ) for cedar in Japan that were similar to those in our study. Despite the high differences in the NRE for the three non-leguminous species, NRP values did not differ significantly. Therefore, the combined use of NRE and NRP gives a better overall understanding of foliar $\mathrm{N}$ movement during the growing season.

Black locust had significantly higher foliar N concentration than the other tree species throughout the growing season. The $\mathrm{N}$ concentration in black locust of green, pre- and post-abscission leaves was also high compared to results for pre- $(1.9-2.3 \% \mathrm{~N})$ and post-abscission $(1.1-1.5 \% \mathrm{~N})$ (Singh $2014,2015)$ and the global average for $\mathrm{N}$-fixing deciduous angiosperms for green $(2.4 \% \mathrm{~N})$ and post-abscission leaf $(1.5 \% \mathrm{~N})$ (Vergutz et al. 2012). In comparison to the other non-leguminous tree species, the NRE was lower, which agrees with previous studies (Lima et al. 2006; Singh 2014). However, the NRE found in our study was lower than in previous studies, which could be due to the tropical environment of the trees in the other studies. In addition, the same species has a lower potential for $\mathrm{N}$ resorption in colder environment than in warmer ones (González-Zurdo et al. 2015; Sun et al. 2016). The establishment of black locust in this site, with its low NRE, changed the soil N characteristics by increasing soil fertility in comparison to the other tree species, as found previously (Chavez-Vergara et al. 2014).

\section{$\delta^{15} \mathrm{~N}$ values and amino acids}

\section{Comparison among tree species}

Leaf $\delta^{15} \mathrm{~N}$ values differed among the four tree species, with leaf $\delta^{15} \mathrm{~N}$ depleted most in beech, and enriched most in larch. The significant enrichment in larch, compared to the other non-leguminous tree species, may originate from the preferential type of $\mathrm{N}$ uptake from the soil, which is generally enriched in ammonium compared to nitrate. In this study, the main form of inorganic $\mathrm{N}$ is ammonium (Seidel et al. 2017), which is also the preferred $\mathrm{N}$ type for larch (Malagoli et al. 2000). Another influence on the $\delta^{15} \mathrm{~N}$ value in the leaves could be mycorrhizal associations of the tree species; plants associated with ectomycorrhizal fungi (ECM) such as beech and larch have depleted $\delta^{15} \mathrm{~N}$ compared to those with arbuscular mycorrhizal fungi (AM) (Michelsen et al. 1996; Schmidt and Stewart 2003) such as cedar. However, larch leaves were in general substantially more enriched in $\delta^{15} \mathrm{~N}$ compared to the other two species, which could indicate a lower reliance on ECM during $\mathrm{N}$ uptake (Hayashi et al. 2018). Differences in leaf $\delta^{15} \mathrm{~N}$ among tree species could also be due to differences in rooting depth, although beech and larch are characterized by shallower rooting, or physiological factors such as different leaf-out dates, which might give one species access to a different $\mathrm{N}$ pool, but that seems unlikely. Therefore, the enriched $\delta^{15} \mathrm{~N}$ values for larch seemed to be due mainly to preferential uptake of 
ammonium and physiological differences in transport, and assimilation of $\mathrm{N}$ between these species (Pardo et al. 2006, 2013), because leaf $\delta^{15} \mathrm{~N}$ values in the present study agree with values found in larch forests of Mongolia (Hayashi et al. 2018). Leaf $\delta^{15} \mathrm{~N}$ in black locust and cedar were similar to tree-ring $\delta^{15} \mathrm{~N}$ values of black locust (close to atmospheric $\delta^{15} \mathrm{~N}=0$ ) and black pine in coastal areas (ranging from -2.0 to $-4.0 \%$ ) of the Shonai Region (Lopez et al. 2014), respectively.

\section{$\delta^{15} \mathrm{~N}$ during the growing season}

The non-N-fixing tree species showed a decreasing trend in $\delta^{15} \mathrm{~N}$ during the growing season, but except for beech, there were no significant differences during $\mathrm{N}$ mobilization from senescent leaves to storage organs, despite significant leaf $\mathrm{N}$ resorption before leaf abscission in all of the tree species. In previous studies, no fractionation of $\delta^{15} \mathrm{~N}$ was found during resorption for various deciduous species (Kolb and Evans 2002; Templer et al. 2007), although these studies did not disprove that this result might be species dependent. Pardo et al. (2013) also found no significant difference between leaf $\delta^{15} \mathrm{~N}$ during the growing season and fresh litter $\delta^{15} \mathrm{~N}$, while Handley et al. (1999) and Näsholm (1994) reported variation in foliar $\delta^{15} \mathrm{~N}$ during the growing season.

In the two early periods, the highest percentage of $\mathrm{N}$ was lost in beech, with $\mathrm{N}$ fractionation from the green to the preabscission leaf $\delta^{15} \mathrm{~N}$, but not from the pre- to the post-abscission leaves. In Scots pine, Näsholm (1994) also found a significant enrichment from green needle to senescent needle, which he hypothesized was due to ammonia volatilization during senescence. This possibility seems unlikely in the present study because leaf $\delta^{15} \mathrm{~N}$ decreased from green leaf to pre-abscission, and not during the main period of senescence. Adriaenssens et al. (2012) found for beech the highest uptake of $\mathrm{N}$ via the air $\left(\delta^{15} \mathrm{~N}=0 \%\right)$ in August, which could contribute to an enriched leaf $\delta^{15} \mathrm{~N}$ values compared to the following months.

For our study, asparagine was the amino acid that increased most from green to pre-abscission leaves in beech (140 times), and thus may have contributed to the lower isotopic values in pre-abscised leaves because it has less $\delta{ }^{15} \mathrm{~N}$ compared to other primary amino acids (Gauthier et al. 2013). Gauthier et al. (2013) found for rapeseed leaves that the free amino acids exhibited high fractionation during enzymatic reactions in primary $\mathrm{N}$ metabolism. Thus, the $\mathrm{N}$ isotope fractionation in beech leaves could be the result of one or more of the above mentioned processes because $\mathrm{N}$ uptake from the air via leaf assimilation during the green leaf period enriched $\mathrm{N}$ in the leaves (Adriaenssens et al. 2012), while the increase in asparagine via protein hydrolysis depleted $\mathrm{N}$ in pre-abscission leaves. Resorption, for deciduous species, is mainly in the form of amino acids
(Babst and Coleman 2018), when no significant $\mathrm{N}$ isotope discrimination was found.

\section{Conclusions}

In this study, the NRE and NRP values for beech, larch and cedar were in a similar range compared to values in previous regional studies and to worldwide averages, while for black locust the NRE was substantially lower than previously found in leguminous species. $\mathrm{N}$ isotope fractionation was only found during leaf $\mathrm{N}$ resorption of beech trees, but only from the green leaf to the pre-abscission period, inferring that it is not due to leaf $\mathrm{N}$ resorption but instead is the result of internal $\mathrm{N}$ metabolic processes. However, these processes did not induce significant $\mathrm{N}$ fractionation in the other species, probably due to variations in the type and amount of free amino acids or the amount of $\mathrm{N}$ that is transported as proteins, although this possibility needs further study.

Acknowledgements We thank technicians Daisuke Arai and Yoshiaki Izuka, of Yamagata University Research Forest and the students of the Watershed Preservation Laboratory, Yamagata University, for their very helpful assistance with fieldwork.

Open Access This article is distributed under the terms of the Creative Commons Attribution 4.0 International License (http://creativeco mmons.org/licenses/by/4.0/), which permits unrestricted use, distribution, and reproduction in any medium, provided you give appropriate credit to the original author(s) and the source, provide a link to the Creative Commons license, and indicate if changes were made.

\section{References}

Adriaenssens S, Hansen K, Staelens J, Wuyts K, De Schrijver A, Baeten L, Boeckx P, Samson R, Verheyen K (2012) Throughfall deposition and canopy exchange processes along a vertical gradient within the canopy of beech (Fagus sylvatica L.) and Norway spruce (Picea abies (L.) Karst). Sci Total Environ 420:168-182

Aerts R (1996) Nutrient resorption from senescing leaves of perennials: are there general patterns? J Ecol 84(4):597-608

Amundson R, Austin AT, Schuur EA, Yoo K, Matzek V, Kendall C, Baisden WT (2003) Global patterns of the isotopic composition of soil and plant nitrogen. Glob Biogeochem Cycles 17(1):1031

Aranibar JN, Otter L, Macko SA, Feral CJW, Epstein HE, Dowty PR, Eckardt FD, Shugart HH, Swap RJ (2004) Nitrogen cycling in he soil-plant system along a precipitation gradient in the Kalahari Sands. Glob Change Biol 10(3):359-373

Babst BA, Coleman GD (2018) Seasonal nitrogen cycling in temperate trees: transport and regulatory mechanisms are key missing links. Plant Sci 270:268-277

Chapin FS, Kedrowski RA (1983) Seasonal changes in nitrogen and phosphorus fractions and autumn retranslocation in evergreen and deciduous taiga trees. Ecology 64(2):376-391

Chavez-Vergara B, Merino A, Vázquez-Marrufo G, García-Oliva F (2014) Organic matter dynamics and microbial activity during decomposition of forest floor under two native neotropical oak 
species in a temperate deciduous forest in Mexico. Geoderma 235:133-145

Chavez-Vergara BM, González-Rodríguez A, Etchevers JD, Oyama K, García-Oliva F (2015) Foliar nutrient resorption constrains soil nutrient transformations under two native oak species in a temperate deciduous forest in Mexico. Eur J For Res 134(5):803-817

Codron J, Codron D, Lee-Thorp JA, Sponheimer M, Bond WJ, de Ruiter D, Grant R (2005) Taxonomic, anatomical, and spatiotemporal variations in the stable carbon and nitrogen isotopic compositions of plants from an African savanna. J Archaeol Sci 32(12): 1757-1772

Craine JM, Elmore AJ, Aidar MP, Bustamante M, Dawson TE, Hobbie EA, Nardoto GB (2009) Global patterns of foliar nitrogen isotopes and their relationships with climate, mycorrhizal fungi, foliar nutrient concentrations, and nitrogen availability. New Phytol 183(4):980-992

Fotelli MN, Rennenberg H, Gessler A (2002) Effects of drought on the competitive interference of an early successional (Rubus fruticosus) on fagus sylvatica L. seedlings: $15 \mathrm{~N}$ uptake and partitioning. Responses of amino acids and other N compounds. Plant Biol 4:311-320

Gauthier NP, Soufi B, Walkowicz WE, Pedicord VA, Mavrakis KJ, Macek B, Miller ML (2013) Cell-selective labeling using amino acid precursors for proteomic studies of multicellular environments. Nat Methods 10(8):768

González-Zurdo P, Escudero A, Mediavilla S (2015) N resorption efficiency and proficiency in response to winter cold in three evergreen species. Plant Soil 394(1-2):87-98

Handley LL, Austin AT, Stewart GR, Robinson D, Scrimgeour CM, Raven JA, Schmidt S (1999) The ${ }^{15} \mathrm{~N}$ natural abundance $\left(\delta^{15} \mathrm{~N}\right)$ of ecosystem samples reflects measures of water availability. Funct Plant Biol 26(2):185-199

Hayashi M, Lopez MCL, Nobori Y, Byambasuren M, Boy J (2018) Nitrogen isotope pattern in Mongolian larch stands at the southern Eurasian boreal forest boundary. Isot Environ Health Stud 45(6):608-621

Hobbie EA, Jumpponen A, Trappe J (2005) Foliar and fungal ${ }^{15} \mathrm{~N}:{ }^{14} \mathrm{~N}$ ratios reflect development of mycorrhizae and nitrogen supply during primary succession-testing analytical models. Oecologia 146(2):258-268

Kahmen A, Wanek W, Buchmann N (2008) Foliar $\delta^{15} \mathrm{~N}$ values characterize soil $\mathrm{N}$ cycling and reflect nitrate or ammonium preference of plants along a temperate grassland gradient. Oecologia 156(4):861-870

Killingbeck KT (2004) Nutrient resorption. Plant cell death processes. Academic Press, Cambridge, pp 215-226

Kobayashi H, Tashiro N (2003) Temporal variation in leaf nitrogen content in a Cryptomeria japonica canopy. J Forest Environ (Jpn) 45(2):99-102

Kolb KJ, Evans RD (2002) Implications of leaf nitrogen recycling on the nitrogen isotope composition of deciduous plant tissues. New Phytol 156(1):57-64

Lima ALDS, Zanella F, Schiavianto MA, Haddad CRB (2006) N availability and mechanisms of $\mathrm{N}$ conservation in deciduous and semideciduous tropical forest legume trees. Acta Bot Bras 20(3):625-632

Lopez CML, Mizota C, Nobori Y, Sasaki T, Yamanaka T (2014) Temporal changes in nitrogen acquisition of Japanese black pine (Pinus thunbergii) associated with black locust (Robinia pseudoacacia). J For Res 25(3):585-589

Mae T (2004) Leaf senescence and nitrogen metabolism. Plant cell death processes. Academic Press, Cambridge, pp 157-168

Malagoli M, Dal Canal A, Quaggioti S, Pegoraro P, Botacin A (2000) Differences in nitrate and ammonium uptake between Scots pine and European larch. Plant Soil 221(1):1-3
Michelsen A, Schmidt IK, Jonasson S, Quarmby C, Sleep D (1996) Leaf ${ }^{15} \mathrm{~N}$ abundance of subarctic plants provides field evidence that ericoid, ectomycorrhizal and non-and arbuscular mycorrhizal species access different sources of soil nitrogen. Oecologia 105(1):53-63

Millard P (1994) Measurement of the remobilization of nitrogen for spring leaf growth of trees under field conditions. Tree Physiol 14(7-8-9):1049-1054

Näsholm T (1994) Removal of nitrogen during needle senescence in Scots pine (Pinus sylvestris L.). Oecologia 99(3-4):290-296

Negi GCS, Singh SP (1993) Leaf nitrogen dynamics with particular reference to retranslocation in evergreen and deciduous tree species of Kumaun Himalaya. Can J For Res 23(3):349-357

Oikawa A, Ostuka T, Nakabayashi R, Jikumaru Y, Isuzugawa K, Murayama H, Saito K, Shiratake K (2015) Metabolic profiling of developing pear fruits reveals dynamic variation in primary and secondary metabolites, including plant hormones. PLoS ONE 10(7): 0131408

Özbucak TB, Kutbay HG, Kilic D, Korkmaz H, Bilgin A, Yalcin E, Apaydin Z (2008) Foliar resorption of nutrients in selected sympatric tree species in gallery forest Black Sea region. Pol J Ecol 56(2):227-237

Pardo LH, Templer PH, Goodale CL, Duke S, Groffman PM, Adams MB, Compton J (2006) Regional assessment of N saturation using foliar and root $\delta^{15} \mathrm{~N}$. Biogeochemistry 80(2):143-171

Pardo LH, Semaoune P, Schaberg PG, EagarC SM (2013) Patterns in ${ }^{\delta}{ }^{15} \mathrm{~N}$ in roots, stems, and leaves of sugar maple and American beech seedlings, saplings, and mature trees. Biogeochemistry 112(1-3):275-291

Santa Regina I, Tarazona T (2001) Nutrient cycling in a natural beech forest and adjacent planted pine in northern Spain. Forestry 74(1):11-28

Schmidt S, Stewart GR (2003) $\delta^{15} \mathrm{~N}$ values of tropical savanna and monsoon forest species reflect root specializations and soil nitrogen status. Oecologia 134(4):569-577

Seidel F, Lopez CML, Guggenberger G, Nobori Y (2017) Impact of low severity fire on soil organic carbon and nitrogen characteristics in Japanese cedar forest, Yamagata Prefecture, Japan. Open J For 7:270-284

Shearer G, Kohl DH (1989) Natural ${ }^{15} \mathrm{~N}$ abundance of $\mathrm{NH}_{4}{ }^{+}$, amide $\mathrm{N}$, and total $\mathrm{N}$ in various fractions of nodules of peas, soybeans and lupins. Funct Plant Biol 16(4):305-313

Singh A (2014) Nitrogen and phosphorus resorption efficiency in some, native tropical trees planted on a mine spoil in Singrauli Coalfields, India. Int J Environ Bioenergy 9(3):161-170

Singh A (2015) Nitrogen and phosphorus resorption efficiency in some leguminous and non-leguminous tropical tree species planted on coal mine spoil in a tropical dry environment. Ambit J Educ Res Rev 1:1-7

Sun X, Kang H, Chen HY, Björn B, Samuel BF, Liu C (2016) Biogeographic patterns of nutrient resorption from Quercus variabilis Blume leaves across China. Plant Biol 18(3):505-513

Tateno R, Takeda H (2010) Nitrogen uptake and nitrogen use efficiency above and below ground along a topographic gradient of soil nitrogen availability. Oecologia 163(3):793-804

Templer PH, Arthur MA, Lovett GM, Weathers KC (2007) Plant and soil natural abundance ${ }^{\delta 15} \mathrm{~N}$ : indicators of relative rates of nitrogen cycling in temperate forest ecosystems. Oecologia 153(2):399-406

Ueda MU, Mizumachi E, Tokuchi N (2011) Foliage nitrogen turnover: differences among nitrogen absorbed at different times by Quercus serrata saplings. Annals of Botany 108(1):169-175

van Heerwaarden LM, Toet S, Aerts R (2003) Current measures of nutrient resorption efficiency lead to a substantial underestimation of real resorption efficiency: facts and solutions. Oikos 101(3):664-669 
Vergutz L, Manzoni S, Porporato A, Novais RF, Jackson RB (2012) Global resorption efficiencies and concentrations of carbon and nutrients in leaves of terrestrial plants. Ecol Monogr 82(2):205-220

Vitousek P, Matson PA, Van Cleve K (1989) Nitrogen availability and nitrification during succession: primary, secondary, and old-field seres. Plant Soil 115(2):229-239

Wang L, Ibrom A, Korhonen JFJ, Frumau KF, Wu J, Pihlatie M, Schjoerring JK (2013) Interactions between leaf nitrogen status and longevity in relation to $\mathrm{N}$ cycling in three contrasting European forest canopies. Biogeosciences 10:999-1011

Wright IJ, Westoby M (2003) Nutrient concentration, resorption and lifespan: leaf traits of Australian sclerophyll species. Funct Ecol 17(1):10-19

Yasumura Y, Onoda Y, Hikosaka K, Hirose T (2005) Nitrogen resorption from leaves under different growth irradiance in three deciduous woody species. Plant Ecol 178(1):29-37
Yoneyama T, Muraoka T, Murakami T, Boonkerd N (1993) Natural abundance of ${ }^{15} \mathrm{~N}$ in tropical plants with emphasis on tree legumes. Plant Soil 153(2):295-304

Yuan Z, Chen HY (2009) Global trends in senesced-leaf nitrogen and phosphorus. Glob Ecol Biogeogr 18(5):532-542

Yuan ZY, Li LH, Han XG, Huang JH, Jiang GM, Wan SQ, Zhang WH, Chen QS (2005) Nitrogen resorption from senescing leaves in 28 plant species in a semi-arid region of northern China. J Arid Environ 63(1):191-202

Publisher's Note Springer Nature remains neutral with regard to jurisdictional claims in published maps and institutional affiliations. 